\title{
Library support for accreditation A guide to online resources
}

$\mathbf{R}$ ecently I was asked to write a letter describing library support for a new program in one of my academic departments. At first I froze, as I had never done this before, and I was not sure where to begin. I was advised to use documentation that had been created for another program as a template, which was helpful, and I wrote a descriptive account of the resources and services provided by the library. The experience generated in me an urge to know more about the role the library plays in the accreditation process and, in particular, the expectations and standards that need to be met by libraries in specific subjects. Some of questions I had were:

- Are there specific books, journals, databases, or other resources that are required or recommended in a subject?

- Are there required or recommended levels related to acquisitions, such as spending or number of resources added in a fiscal or academic year?

- Is there mention of other types of resources that should be available in departments, such as test kits, evaluation instruments, or teaching aids for Education and Educational Psychology?

- Is there a standard for collection size for books or journals?

- Are there any standards related to library services (interlibrary loan, computer stations, printers, and scanners) or number of library personnel available to work with students and faculty?

My institution, Western Connecticut State University, has overall accreditation through one of the seven regional bodies, the Northeast
Association of Schools and Colleges (NEASC). Three of my departments have accreditation through discipline-focused bodies: the National Council of Accreditation for Teacher Education, the Commission on Collegiate Nursing Education, and the American Chemical Society. So I was interested in what these agencies had to say in their standards.

I expected, somewhat naively in hindsight, the information these agencies provide would answer my questions. I looked at the websites, and accompanying standards, of the relevant accreditation bodies, and I was surprised to see very little written about the resources, services, and overall role the library was expected to play. I found many standards have generalist language such as "library resources and services are adequate for students and faculty to meet program requirements." That being the case, I have learned that I had an open platform I could fill with descriptions of library resources and services.

The resources on this guide provide information on accreditation from a variety of perspectives. First there are the national, regional, and disciplinary accreditation agencies. After that there are perspectives and activities as seen by librarians and libraries in the form of articles,

Tom Schmiedel is public services librarian, librarian for Education and Educational Psychology, Health Promotion and Exercise, Nursing, and Chemistry at Western Connecticut State University's Ruth A. Haas Library, email: schmiedeltf@wcsu.edu

(C) 2017 Tom Schmiedel 
presentations, LibGuides, and institutional repositories. Keep in mind this is not a complete list of accreditation bodies, but rather a selection of those available. If you want to see others not listed, consult one of the national databases for the subject area.

\section{Accreditation bodies}

National level

On the national level two entities serve as a clearinghouse for all other accreditation bodies. The national bodies are the Council for Higher Education Accreditation (CHEA) and the U.S. Department of Education (DOE) with its Database of Accredited Postsecondary Institutions and Programs. These two entities provide assurance that accreditation bodies meet the quality standards of the respective organization, either CHEA or DOE or both.

- Council for Higher Education Accreditation (CHEA). The CHEA site lists about 25 institutional and 70 program accreditation bodies and has a variety of information about the accreditation process, including an informative Accreditation Toolkit. One can search institutions to see accreditations earned or search accredi-

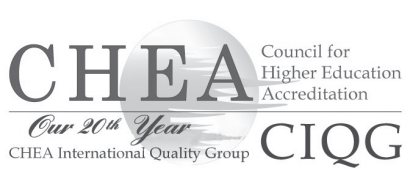

tation program types or bodies to see which institutions

have a particular accreditation. CHEA provides a list of agencies that are recognized by CHEA, DOE, or both. Access: http://www.chea.org/ and http://www.chea.org/pdf/CHEA_USDE_Al1Accred.pdf.

- DOE, Database of Accredited Postsecondary Institutions and Programs. This site lists about 30 institutional and 40 program accreditation bodies and includes the Information on Accredited Institutions, Accreditor Recognition Criteria and Process, Information on Recognized Accreditors, and Recommendations on Improving Accreditation. Use the Databases of Accredited Post-Secondary Institutions and Programs to search institutions, to see accreditations earned or search accreditation bodies, and to see which institutions have a particular accreditation. Access: http://www.ed.gov /accreditation? src $=$ accred.

\section{Regional level}

On the regional level there are seven main entities that provide accreditation for institutions of higher education. These entities cover institutions within state boundaries as indicated below. The standards for each vary considerably in content involving libraries. Some mention libraries in a general sense, such as the Higher Learning Commission, while others have specific sections addressing libraries, such as the Northwest Commission on Colleges and Universities.

- Higher Learning Commission. The Higher Learning Commission covers the North Central States of Arizona, Arkansas, Colorado, Illinois, Indiana, Iowa, Kansas, Michigan, Minnesota, Missouri, Nebraska, New Mexico, North Dakota, Ohio, Oklahoma, South Dakota, West Virginia, Wisconsin, and Wyoming. There is no specific section in the standards for libraries but mentions libraries in one standard: Criterion 3, Teaching and Learning: Quality, Resources, and Support. Information literacy is not mentioned. Access: Home page: https:// www.hlcommission.org/, Standards: https:// www.hlcommission.org/Criteria-Eligibility-and -Candidacy/criteria-and-core-components.html.

- Middle States Commission on Higher Education (MSCHE). MSCHE covers the Mid-Atlantic States of Delaware, Maryland, New Jersey, New York, and Pennsylvania. It also covers the District of Columbia, Puerto Rico, and the U.S. Virgin Islands. There is no specific section in the Standards for libraries. Mentions libraries in four standards: Standard 3, Institutional Resources, Standard 9, Student Support Services, Standard 11, Educational Offerings, and Standard 13, Related Educational Activities. Mentions information literacy in Standards 11, 12 (General Education), and 13. Access: Homepage: https://www.msche. org/, Standards: https://www.msche.org /publications/CHX-2011-WEB.pdf.

\section{$\begin{array}{ll}\mathrm{CHE} & \begin{array}{l}\text { MIDDLE STATES COMMISSION } \\ \text { ON HIGHER EDUCATION }\end{array}\end{array}$}

- New England Association of Schools and Colleges. The New England Association of Schools and Colleges covers New England 
States of Maine, New Hampshire, Vermont, Massachusetts, Rhode Island, and Connecticut. There is no specific section in the standards for libraries but mentions libraries in two standards: Standard 6, Teaching, Learning and Scholarship, and Standard 7, Institutional Resources. Information literacy is mentioned in Standard 4, The Academic Program. Access: Homepage: https:// cihe.neasc.org/, Standards: https://cihe.neasc. org/standards-policies/standards-accreditation /standards-effective-july-1-2016.

- Northwest Commission on Colleges and Universities (NWCCU). NWCCU covers the Northwest States of Alaska, Idaho, Montana, Nevada, Oregon, Utah, and Washington. Section $2 \mathrm{E}$ of the Standards is dedicated to library and information sources specifically. It mentions libraries in one other standard, Standard 2, Resources and Capacity. Information literacy is not mentioned. Access: Homepage: http://www. nwccu.org/, Standards: http://www.nwccu.org /Pubs\%20Forms\%20and\%20Updates /Publications/Standards\%20for $\% 20$ Accreditation.pdf.

- Southern Association of Colleges and Schools Commission on Colleges (SACS-COC). SACS-COC covers the Southern and South Central States of Alabama, Florida, Georgia, Kentucky, Louisiana, Mississippi, North Carolina, South Carolina, Tennessee, Texas, and Virginia. Section 3.8 of the standards is dedicated to Library and Other Learning Resources. It mentions libraries in two standards, Section 2, Core Requirements, and Section 3, Comprehensive Standards, and it does not mention information literacy. Access: Homepage: http://www. sacscoc.org/, Standards: http://www.sacscoc. org/pdf/2012PrinciplesOfAcreditation.pdf.

- Western Association of Schools and Colleges (WASC) Senior School and College Commission. WASC covers the Pacific States of California and Hawaii. There is no specific section in the Standards for libraries. It mentions libraries, as well as information literacy, in Standard 2, Achieving Educational Objectives Through Core Functions. Access: Homepage: https://www.wascsenior.org/, Standards: https://wascsenior.box.com/shared/static /oxgx719tnw5bn8b4kp28.pdf.
- Accrediting Commission for Community and Junior Colleges, Western Association of Schools and Colleges (ACCJC). ACCJC covers the Pacific States of California and Hawaii. Standard II-B of the Standards is dedicated to Library and Learning Support Services. It does not mention information literacy. Access: Homepage: http://www.accjc.org/, Standards: http:// www.accjc.org/wp-content/uploads/2014/07 /Accreditation_Standards_Adopted_June_2014. pdf.

In addition to the above national/regional agencies, the DOE site lists several specialized agencies, a few of which are listed here.

- Accrediting Commission of Career Schools and Colleges. Within Standard Section II-7, Program Requirements-Learning Resource System (LRS), the library is addressed as one of the main components of the LRS. There are six bullet points that include information related to types of library resources, integration into the curriculum, and management of the system by someone with a master's degree in library or information science. Access: Homepage: http://www.accsc.org/, Standards: http://www. accsc.org/UploadedDocuments/ACCSC $\% 20$ Standards $\% 20$ of $\% 20$ Accreditation $\% 20$ and $\% 20$ Bylaws\%20-\%20070116.pdf.

- Distance Education Accrediting Commission. This site contains a generalist perspective, stating that the "institution provides faculty and students with access to learning resources

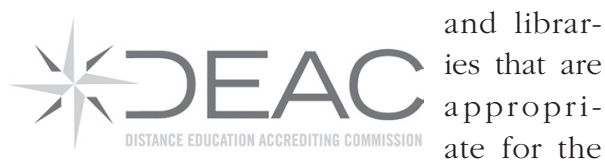
achievement of program learning outcomes." Access: Homepage: http://www. deac.org/, Standards: http://www.deac.org /UploadedDocuments/2016-Handbook /2016-Accreditation-Handbook-Part-Three.pdf.

- Transnational Association of Christian Colleges and Schools, Accreditation Commission. Standards Section II-J, Library and Learning Resources, has seven bullet points that address library resources and services, financial support, staffing, instruction, and online availability. Access: Homepage: 
http://www.tracs.org/, Standards: http:// www.tracs.org/documents/2015DecemberAc creditationManual.pdf.

\section{Disciplinary areas (program accreditations)}

The CHEA database lists about 70 program accreditations, while the DOE database lists about 40 program accreditations. A sampling of these programs are listed here.

- Accreditation Board for Engineering and Technology (ABET). There are four commissions in ABET: Applied Access, Computing, Engineering, and Engineering Technology. The "Accreditation Policy and Support Manual" does not address library resources or services. There is a self-study template that states (Section 7E, Facilities, Libraries): "Describe and evaluate the capability of the library (or libraries) to serve the program including the adequacy of the library's technical collection relative to the needs of the program and the faculty, the adequacy of the process by which faculty may request the library to order books or subscriptions, the library's systems for locating and obtaining electronic information, and any other library services relevant to the needs of the program." Access: Homepage: http://www.abet.org/accreditation/, Manual: http://www.abet.org/wp-content /uploads/2015/10/A001-16-17-Accreditation -Policy-and-Procedure-Manual-11-1-15.pdf.

- American Chemical Society (ACS) Approval Program for Bachelor's Degree. In section 4.4 of the Guidelines and Evaluation Procedures for Bachelor's Degree Programs, ACS requires that students have access to a minimum number of journals from a range of chemistry disciplines, access to additional journal articles through interlibrary loan, and searchable access to Chemical Abstracts. Access: https://www. acs.org/content/acs/en/about/governance /committees/training/acsapproved.html.

- American Psychological Association, Commission on Accreditation (APA-CoA).

APA-CoA does not accredit schools or universities or programs at the bachelor's or master's levels. It accredits doctoral level programs, internships associated with doctoral level work, and postdoctoral residency programs. Access: http://www.apa.org /ed/accreditation/about/coa/.
- Commission on Collegiate Nursing Education (CCNE), Baccalaureate \& Graduate Nursing Programs. CCNE does not provide details specific to library resources or services. There is a general statement in Standard II-B: "Academic support services (e.g., library, technology, distance education support, research support, admission, and advising services) are adequate for students and faculty to meet program requirements and to achieve the mission, goals, and expected program outcomes. There is a defined process for regular review of the adequacy of the program's academic support services. Review of academic support services occurs and improvements are made as appropriate." Access: Homepage: http://www. ccneaccreditation.org, Standards: http://www. aacn.nche.edu/ccne-accreditation/standardsprocedures-resources/baccalaureate-graduate.

- Commission on English Language Program Accreditation. The Standards have eleven sections including mission, curriculum, student services, and facilities, equipment, and supplies. The library is not mentioned in the 59 page document. Access: Homepage: http://www.cea-accredit. org/, Standards: http://www.cea-accredit.org /images/2016_CEA_Standards.pdf.

- Council for the Accreditation of Educator Preparation (CAEP) Standards. There are five standards, but there is no mention of libraries or library resources or services. The only use of the word library is in reference to a school library media specialist as a school professional who may have an instructional role. Access: Homepage: http://caepnet.org/accreditation /caep-accreditation/caep-accreditation-resources, Standards: http://caepnet.org/ /media/Files /caep/standards/final-board-amended -20150612.pdf.

- Council on Education for Public Health. Section C5, Information and Technology Resources, includes a statement that "briefly describe, with data if applicable, library resources and support available for students and faculty." Access: Homepage http://ceph.org /about/understanding-accreditation/, Standards: http://ceph.org/criteria-procedures/.

- National Association of Schools of Art and Design, Commission on Accredita- 
tion. Standards Section G, Library and Learning Resources, is comprised of two full pages of standards, including main headings of overall requirements, governance and administration, collections, personnel, services, facilities, and finances. The comprehensive section has more than 20 bullet points addressing library requirements. Access: Homepage https://www.arts -accredit.org/, Standards: https://nasad.arts -accredit.org/wp-content/uploads/sites/3/2015/11 /NASAD_HANDBOOK_2016-17.pdf.

\section{Library perspectives and activities}

This section provides some examples of the types of information academic institutions and libraries provide, as well as a variety of formats with which they present information.

- Assessing Support for Academic Program Accreditations. This paper was presented at the ACRL 2013 Conference in April 2013 by Felix T. Chu, Western Illinois University Libraries. Chu creates a checklist based on accreditation standards of several accreditation bodies and maps the checklist to the nine principles of the ACRL Standards for Libraries in Higher Education. Access: http://www.ala.org /acrl/sites/ala.org.acrl/files/content /conferences/confsandpreconfs/2013/papers /Chu_AssessingSupport.pdf.

- Ivy Tech Community College, Nursing Accreditation. This LibGuide has sections that provide a look at resources available at Ivy Tech to fulfill the requirements for certification by the National League of Nursing Accreditation Committee. Access: http://library.ivytech.edu /Nursing-NLNvisit.

- Pacific Lutheran University, Accreditation: 2.E.1 Access to Library and Information Resources. This LibGuide has tabs for each section of Standard 2 (WASC). There is also "snapshot" information about one day of activity, "a day in the life," for each of the past five years (web visits, door count, LibGuides stats, item checkouts, interlibrary loan, and information from library surveys. Access: http://findit.library.plu. edu/c.php?g=316913\&p=2115561.

- Preparing a Library for SACS-COC Reaffirmation of Accreditation (Southern
Association of Colleges and Schools Commission on Colleges). Presentation by Alice Daugherty, assessment librarian at Louisiana State University Libraries, from 2013. Topics include information about SACS-COC, basics of accreditation, the library's role, documentation needed, and challenges and opportunities (18 slides). Access: https://sites01.lsu.edu/wp/louis /files/2013/10/daugherty_SACSCOC.pdf.

- Preparing for Reaccreditation. Presentation by Patricia O'Brien, NEASC senior vice president at the University of Rhode Island, June 2016. Topics include accreditation basics, new standards, the self-study, using data effectively, and the team's site visit ( 45 slides). Access: http:// slideplayer.com/slide/10844106/.

- UConn NEASC Accreditation in 2006/2007. This contains individual documents (PDFs) for download providing introduction and overview, self-study committee members, NEASC visiting team members, and standards 1-11, including Standard 7, Library and Information Resources. Access: http://digitalcommons. uconn.edu/accred_neasc/.

- Umpqua Community College. This site provides a LibGuide with documentation of their accreditation process including Accreditation

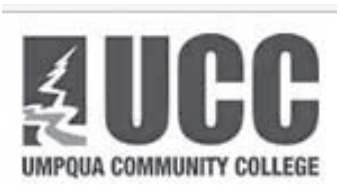
Standards (ACCJC), examples of other institutions' sevenyear accreditation reports, accreditation committee notes, and Accreditation Standard 2 (Library and Learning Support Services) Year 3 Report. Access: http://guides.ucclibrary. com/c.php?g=541665.

- University of New Mexico. This LibGuide provides a variety of assessment and accreditation information, including LibQual results, annual reports, and accreditation self-study documents from the past cycle (2008-09). Access: http://libguides.unm.edu/c. php?g=416079\&p=2838343.

- University of Southern Maine, NEASC Accreditation 2011 and Five year Interim Report 2016. The site includes self-studies and resources used in preparing the studies. Access: https://usm.maine.edu/accreditation/neasc-selfstudy-document-repository. $\mathrm{z}$ 